\title{
Physical Signs of Illness, Liver Functions and Reproductive Parameters of Female Rats Supplemented with Melaleuca cajuputi Methanolic Extract
}

\author{
Dzulsuhaimi Daud $^{1 *}$, Nur Lisma Ruhila Alias ${ }^{1}$, Mohd Tajudin Mohd Ali ${ }^{1}$, Alene Tawang ${ }^{2}$ \\ ${ }^{1}$ Faculty of Applied Sciences, Universiti Teknologi MARA, 40450 Shah Alam, Selangor, Malaysia. \\ ${ }^{2}$ Faculty of Science and Mathematics, Universiti Pendidikan Sultan Idris, 35900 Tanjong Malim, Perak, Malaysia.
}

\begin{tabular}{|c|c|}
\hline ARTICLE INFO & ABSTRACT \\
\hline Article history: & Melaleuca cajuputi is the main source of cajuput essential oil, which is widely used in the folk medicine in southeastern \\
\hline Received on: $18 / 01 / 2018$ & Asia. The study aimed to determine the effect of $M$. cajuputi methanolic extract (MCME) on liver functions and \\
\hline Accepted on: $15 / 02 / 2018$ & fertility of female Sprague Dawley rats. Twenty four female rats were divided into four groups and supplemented with \\
\hline Available online: $29 / 04 / 2018$ & $\begin{array}{l}2 \mathrm{ml} / \mathrm{kg} \text { bwt distilled water or several doses of } \operatorname{MCME}(50,100 \text {, and } 200 \mathrm{mg} / \mathrm{kg} \text { bwt) for } 30 \text { days. Physical signs of } \\
\text { illness were observed on a daily basis. Blood was collected at the end of the experimental period for liver functions }\end{array}$ \\
\hline $\begin{array}{l}\text { Key words: } \\
\text { Melaleuca cajuputi, toxicity, } \\
\text { liver functions, estrogen } \\
\text { assay, in-vivo fertilization. }\end{array}$ & $\begin{array}{l}\text { and estrogen assay. All females also subjected to fertility test. No signs of illness and mortality were observed. Results } \\
\text { also demonstrated that liver functions, estrogen level and fertility in female Sprague Dawley rats were not affected } \\
\text { by MCME. These findings suggested that MCME at doses in between 50-200 mg/kg bwt were not toxic to female } \\
\text { Sprague Dawley rats. }\end{array}$ \\
\hline
\end{tabular}

\section{INTRODUCTION}

The Melaleuca genus is an aromatic and medicinal plant genus, best known for the production of essential oils (Barbosa et $a l ., 2013)$. This genus grows as a shrub or tree with single flexible trunk ranging from a small tree to tree with 25 meters in height. Melaleuca cajuputi is the most widespread Melaleuca species, extending from northern Australia, Papua New Guinea, Indonesia, Malaysia, Thailand, Cambodia, and Vietnam (Craven, 1999). This species is well adapted to seasonally flooded soils, even salt-water flooding, and infertile soils. M. cajuputi contains eucalyptol, which is a monoterpene with medicinal purposes (Boland et al., 1991). Traditionally, $M$. cajuputi is used as a medicine to treat cholera, diarrhea, muscular pain, scabies and intestinal worms (Al-Abd et al., 2016). Pre-clinical data demonstrated that $M$. cajuputi possess anti-inflammatory, anti-bacterial, anti-microbial, anti-dengue, anti-oxidant, anti-cancer and anticonvulsant activities (Daud

"Corresponding Author

Dzulsuhaimi Daud, Faculty of Applied Sciences, Universiti Teknologi

MARA, 40450 Shah Alam, Selangor, Malaysia.

E-mail:dzuls990@gmail.com et al., 2015). Widiana et al. (2014) reported that solid residue of $M$. cajuputi leaves rich with volatile fatty acids, dry matter digestibility, and organic matter digestibility, thus, has a potential to be used as a livestock feed.

However, very few studies have addressed the toxicity effect of $M$. cajuputi on reproductive as well as the nonreproductive system. Roszaini et al. (2013) documented that M. cajuputi essential oil less toxic against subterranean termite, Coptotermes curvignathus. Acute toxicity studies demonstrated that the lethal dose of cajuput oil derived from M. cajuputi was $5 \mathrm{~g} / \mathrm{kg}$ in mice and $3870 \mathrm{mg} / \mathrm{kg}$ in rats (Russell, 1999). Previous authors reported that methanolic extract of $M$. cajuputi leaves at $200 \mathrm{mg} / \mathrm{kg}$ was not toxic to the male reproductive system of juvenile Sprague Dawley rats (Daud et al., 2015). As far as our literature survey could ascertain, no attempts have been made to investigate the effect of this plant on the female reproductive system. Reproductive toxicology has recently become a rapidly extending area of research and testing. Since herbal and plantbased medicine have recently become a widespread form of therapy, reproductive toxicity should be considered as part of 
the safety evaluation process. Hence, the present study has been directed towards investigating the action of the M. cajuputi leaves methanolic extract on the female reproductive system in rats. In addition, the effect of this crude extract on the nonreproductive system (particularly on the liver functions) also has been investigated.

\section{MATERIALS AND METHODS}

\section{Plant materials collection and methanolic extraction}

Melaleuca cajuputi fresh leaves were collected in MayJuly 2012 from their natural habitats in Selangor, Malaysia. The plant was botanically identified by plant specialist from Herbarium, Universiti Kebangsaan Malaysia with voucher specimen number NLRA 3/A/2012. The leaves were washed thoroughly, airdried and subjected to size reduction using an electrical blender (Pensonic PB-3203L, Malaysia). Then, the leaves were soaked in $80 \%$ methanol (HmbG Chemicals, Germany) for three days. The filtrate was collected and evaporated under reduced pressure using rotary evaporator (Buchi Rotavapor R-210, Switzerland). The $M$. cajuputi methanolic extract (MCME) obtained was stored in a container and was freshly reconstituted with distilled water immediately before administration to the female rats.

\section{Experimental animals and experimental design}

The handling of the laboratory animals was performed according to the national and international regulations and the prior ethical approval was taken before starting the experiment (AREC 3/669/07). All animals were maintained in a temperaturecontrolled room $\left(22 \pm 1^{\circ} \mathrm{C}\right)$ under uniform lighting and were given commercial rat chow pellets (Gold Coin Feedmills Sdn Bhd, Malaysia) and water ad-libitum. Twenty-four female Sprague Dawley rats were divided into four groups with six animals each. Group $1(n=6)$ was served as a control and orally supplemented with $2 \mathrm{ml} / \mathrm{kg}$ bwt of distilled water. Group 2-4 ( $\mathrm{n}=6$ for each group) were supplemented with 50,100 , and $200 \mathrm{mg} / \mathrm{kg}$ bwt of M. cajuputi leaves methanolic extract (MCME), respectively. All the animals were supplemented with respective doses of MCME for 30 days. Physical signs of illness and toxicity (piloerection, lethargy, hair loss, dark urine, diarrhoea, paleness of skin, locomotor activity and mortality) were monitored, twice daily at 7 am and 5 pm as previously described (Basir et al., 2012). After 30 days of the experimental period, all animals were subjected to several tests including liver functions test, estrogen assay, and fertility test.

Table 1: Physical signs of illness among female Sprague Dawley rats supplemented with distilled water $\left(\mathrm{dH}_{2} \mathrm{O}\right)$ or different doses of $M$. cajuputi methanolic extracts (MCME).

\begin{tabular}{|c|c|c|c|c|}
\hline Physical signs & 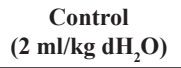 & $\begin{array}{c}\text { MCME } \\
\text { (50 } \mathrm{mg} / \mathrm{kg} \text { bwt) }\end{array}$ & $\begin{array}{c}\text { MCME } \\
(100 \mathrm{mg} / \mathrm{kg} \text { bwt })\end{array}$ & $\begin{array}{c}\text { MCME } \\
\text { (200 } \mathrm{mg} / \mathrm{kg} \text { bwt) }\end{array}$ \\
\hline Piloerection & - & - & - & - \\
\hline Lethargy & - & - & - & - \\
\hline Hair loss & - & - & - & - \\
\hline Dark urine & - & - & - & - \\
\hline Diarrhoea & - & - & - & - \\
\hline Paleness of skin & - & - & - & - \\
\hline Locomotors & Active & Active & Active & Active \\
\hline Mortality & - & - & - & - \\
\hline
\end{tabular}

Note: + (presence of the sign of illness), - (absence of the sign of illness).

\section{Blood collection, liver functions, and estrogen assay}

The blood was collected in the morning, via retroorbital bleeding into $\mathrm{K}_{2}$ EDTA tube. Blood serum was harvested and subjected to liver functions test (ALT, AST, ALP, and TP) and estrogen assay. Analysis of serum alanine aminotransferase (ALT) and aspartate aminotransferase (AST) was performed by ReitmanFrankel colorimetric method (Reitman and Frankel, 1957). Serum alkaline phosphatase (ALP) was estimated as previously described by Kind-King method (Kind and King, 1954). Total protein (TP) was determined by biuret method (Doumas, 1975). The estrogen level was measured by quantitative enzyme immunoassay using Enzyme-linked Immunosorbent Assay Kit for Estrogen (CloudClone Corp, USA) according to manufacturer's manual.

\section{Fertility test}

Fertility test was conducted as previously described (Al-Hamood et al., 1998). Female rats were mated with proven fertile males and the presence of copulation plug or sperm in the vaginal smear in the following morning was regarded as a day 1 of pregnancy. All females were sacrificed on the day 20 of pregnancy under diethyl ether anesthesia. During the autopsy, the number of a foetus along the uterine horns were recorded.

\section{Statistical analysis}

The results were expressed as mean \pm SEM. All data were analyzed by analysis of variance (ANOVA) and $p$ values less than 0.05 were considered significant.

\section{RESULTS AND DISCUSSION}

\section{Physical signs of illness and liver functions test}

Daily supplementation of $M$. cajuputi methanolic extract (MCME) for 30 days was well tolerated and no physical signs of illness were observed in female rats (Table 1). The findings also demonstrated that alanine aminotransferase (ALT), aspartate aminotransferase (AST), alkaline phosphatase (ALP) and total 
protein (TP) did not differ significantly ( $p>0.05)$ among female Sprague Dawley rats supplemented with distilled water (control) or with different doses of MCME (Table 2). No significant variations in behaviors, health conditions, zero mortality and liver functions parameters (ALT, AST, ALP, and TP) were basic evidence indicating the non-toxic nature of MCME. Liver functions can be detrimentally altered by toxicants. The liver is the first organ to encounter drugs and environmental toxicants that enter the hepatic portal vein from the digestive system (Shyamal et al., 2010).

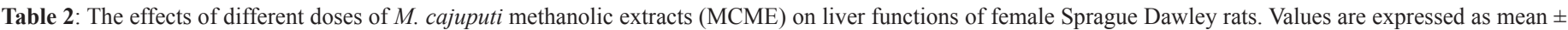
$\operatorname{SEM}(n=6)$.

\begin{tabular}{|c|c|c|c|c|}
\hline Parameters & $\begin{array}{c}\text { Control } \\
\left(2 \mathrm{ml} / \mathrm{kg} \mathrm{dH}_{2} \mathrm{O}\right)\end{array}$ & $\begin{array}{c}\text { MCME } \\
\text { (50 } \mathrm{mg} / \mathrm{kg} \text { bwt) }\end{array}$ & $\begin{array}{c}\text { MCME } \\
(100 \mathrm{mg} / \mathrm{kg} \text { bwt })\end{array}$ & $\begin{array}{c}\text { MCME } \\
(200 \mathrm{mg} / \mathrm{kg} \text { bwt })\end{array}$ \\
\hline ALT (U/l) & $49.48 \pm 3.18$ & $53.79 \pm 9.21$ & $51.13 \pm 6.83$ & $52.43 \pm 2.95$ \\
\hline $\operatorname{AST}(\mathrm{U} / \mathrm{l})$ & $73.35 \pm 2.64$ & $76.35 \pm 4.29$ & $72.99 \pm 1.09$ & $75.61 \pm 3.27$ \\
\hline $\operatorname{ALP}(\mathrm{U} / \mathrm{l})$ & $153.60 \pm 7.81$ & $146.83 \pm 8.42$ & $149.11 \pm 5.39$ & $150.98 \pm 4.15$ \\
\hline TP $(g / l)$ & $75.37 \pm 4.37$ & $72.73 \pm 6.11$ & $70.15 \pm 2.95$ & $74.44 \pm 2.07$ \\
\hline
\end{tabular}

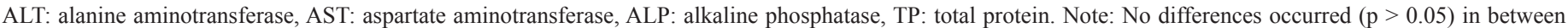
treatments.

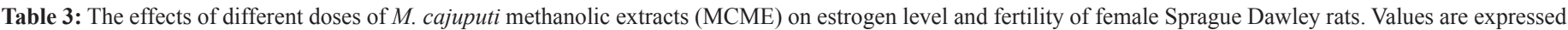
as mean $\pm \operatorname{SEM}(n=6)$.

\begin{tabular}{|c|c|c|c|c|}
\hline Parameters & $\begin{array}{c}\text { Control } \\
\left(2 \mathrm{ml} / \mathrm{kg} \mathrm{dH}_{2} \mathrm{O}\right)\end{array}$ & $\begin{array}{c}\text { MCME } \\
\text { (50 } \mathrm{mg} / \mathrm{kg} \text { bwt) }\end{array}$ & $\begin{array}{c}\text { MCME } \\
(100 \mathrm{mg} / \mathrm{kg} \text { bwt })\end{array}$ & $\begin{array}{c}\text { MCME } \\
(200 \mathrm{mg} / \mathrm{kg} \mathrm{bwt})\end{array}$ \\
\hline Estrogen $(\mathrm{ng} / \mathrm{ml})$ & $8.37 \pm 0.15$ & $8.23 \pm 1.09$ & $7.98 \pm 0.47$ & $8.13 \pm 0.29$ \\
\hline Pregnancy (\%) & 100 & 100 & 100 & 100 \\
\hline Foetus (n) & $8.6 \pm 1.7$ & $8.3 \pm 1.8$ & $8.8 \pm 1.2$ & $8.5 \pm 1.4$ \\
\hline
\end{tabular}

Note: No differences occurred $(p>0.05)$ in between treatments.

Previously, Hammer and co-authors (2006) indicated that Melaleuca species has the potential to be developmentally toxic if ingested at higher doses, especially in the form of essential oil with a high concentration of terpinen-4-ol. Moderate increases in ALT and AST were reported in cats exposed dermally to concentrated Melaleuca species essential oil (Bischoff and Guale, 1998). Our results contradict others, where no signs of toxicity were detected. Perhaps, this can be explained by the different doses and extracts used. In the current study, crude methanolic extract of $M$. cajuputi was tested on female Sprague Dawley rats at a relatively low dose (50-200 mg/kg). Meanwhile, other researchers focused their investigations on the toxicity effects of concentrated essential oil harvested from several Melaleuca species, namely M. cajuputi and M. alternifolia.

\section{Estrogen level and fertility test}

Estrogen assay revealed that circulating estrogen in female rats was not significantly $(p>0.05)$ affected by MCME supplementation (Table 3 ). The percentage of pregnant females and the number of the foetus also did not differ significantly $(p>0.05)$ in between female Sprague Dawley rats received distilled water (control) compared to female Sprague Dawley rats supplemented with different doses of MCME (Table 3).

The pituitary-gonadal axis is important for the maintenance of the reproductive system, any distortion to this axis can be deleterious (Adewale et al., 2014). Female reproductive hormones are crucial for ovulation, preparing the uterus for embryo implantation and also milk production. To date, there is no report on the reproductive toxicity of this plant, particularly in the female. Our findings suggest that MCME at doses in between
$50-200 \mathrm{mg} / \mathrm{kg}$ bwt were not harmful to the reproductive system of female Sprague Dawley rats. However, according to the previously published work, eucalyptol is a major component of $M$. cajuputi leaves (Barbosa et al., 2013; Boland et al., 1991; Russell, 1999) and eucalyptol has been demonstrated to possess insecticidal activities (Wu et al., 2015). Exposure to high concentration of insecticide during pregnancy proves to have a negative impact on embryo development. Therefore, it is rational to assume MCME at very high doses may involve in abortifacient and anti-fertility activities. Further MCME mechanism of action in the female reproductive system should be explored in the future experiments.

\section{CONCLUSION}

From the evidence presented in this study, 50-200 mg/ $\mathrm{kg}$ bwt of $M$. cajuputi methanolic extract (MCME) has apparently demonstrated non-toxic effects on the non-reproductive system (particularly on liver functions) and on the reproductive system in female Sprague Dawley rats. However, the toxicology studies on MCME are still lacking at this stage. Thus, further investigation on acute and sub-chronic toxicity of MCME are required.

\section{ACKNOWLEDGMENT}

This work was financially supported by the Faculty of Applied Sciences and the Institute of Research Management and Innovation (IRMI), Universiti Teknologi MARA, Malaysia.

\section{CONFLICT OF INTEREST AND AUTHOR'S CONTRIBUTION}

The authors declare that there is no conflict of interests regarding the publication of this paper. All authors were involved 
in the writing, revision and final approval of the paper.

\section{REFERENCES}

Adewale OO, Oduyemi OI, Ayokunle O. Oral administration of leaf extracts of Momordica charantia affect reproductive hormones of adult female. Asian Pac J Trop Biomed, 2014; 4:S521-S524.

Al-Abd NM, Nor ZM, Mansor M, Hasan MS, Kassim M. Antifilarial and antibiotic activities of methanolic extracts of Melaleuca cajuputi flowers. Korean J Parasitol, 2016; 54:273-280.

Al-Hamood MH, Elbetieha A, Alkofahi A, Bataineh $\mathrm{H}$. Reproductive toxicity potentials of Saliba fruticosa in rats. J Ethnopharm, $1998 ; 61: 67-74$

Barbosa LCA, Silva CJ, Teixeira RR, Meira RMSA, Pinheiro AL. Chemistry and biological activities of essential oils from Melaleuca L. species. Agric Conspec Sci, 2013; 78:11-23.

Basir R, Chan KL, Yam MF, Abdullah WO, Moklas MAM, Rahim ASA, Ismail IS, Hidayat MT, Taib CN, Mahmud R. Antimalarial activity of selected Malaysian medicinal plants. Phytopharmacology, 2012; 3:82-92.

Bischoff K, Guale FJ. Australian tea tree (Melaleuca alternifolia) oil poisoning in three purebred cats. Vet Diagn Invest, 1998; 10:201-210.

Boland D, Biophy JJ, House APN. 1991. Eucalyptus Leaf Oils: Use, Chemistry Distillation and Marketing. Australia: ACIAR Report.

Craven LA. 1999. Behind The Names: The Botany of Tea Tree, Cajuput and Niaouli (Medicinal and Aromatic Plants-Industrial Profiles). Australia: Harwood Academic Publishers.

Daud D, Gan NNMS, Ali MTM, Tawang A. The effect of Melaleuca cajuputi methanolic leaves extract on body growth, puberty and sperm quality of juvenile male rats. BioTech An Indian J, 2015; 11:115-119.

Doumas BT. Standards for total serum protein assays: A collaborative study. Clin Chem, 1975; 21:1159-1166.

Hammer KA, Carson CF, Riley TV, Nielsen JB. A review of the toxicity of Melaleuca alternifolia (tea tree) oil. Food Chem Toxicol, 2006; 44:616-625.

Kind PRN, King IJ. The determination of serum acid and alkaline phosphatase activity with 4-aminoantipyrine (AAP). J Clin Pathol, $1954 ; 7: 322-326$

Reitman S, Frankel S. A colorimetric method for determination of serum glutamate oxaloacetic and and glutamic pyruvic transaminase. Am J Clin Pathol, 1957; 28:56-63.

Roszaini K, Nor Azah MA, Mailina J, Zaini S, Faridz ZM. Toxicity and antitermite activity of the essential oils from Cinnamomum camphora, Cymbopogon nardus, Melaleuca cajuputi and Dipterocarpus sp. against Coptotermes curvignathus. Wood Sci Technol, 2013; 47:1273-1284.

Russell M. 1999. Toxicology of Tea Tree Oil (Medicinal and Aromatic Plants-Industrial Profiles). Australia: Harwood Academic Publishers.

Shyamal S, Latha PG, Suja SR, Shine VJ, Anuja GI, Sini S, Pradeep S, Sikha P, Rajasekharan S. Hepatoprotective effect of three herbal extracts on aflatoxin B1-intoxicated rat liver. Singapore Med J, 2010; 51:326-331.

Widiana A, Rahman T, Limin SH, Hernaman I, Manurung R. Utilization of solid residue Melaleuca cajuputi Powell leaves as cattle feed. Pak J Nutr, 2014; 13:554-556.

Wu Y, Zhang WJ, Huang DY, Wang Y, Wei JY, Li ZH, Sun JS, Bai JF, Tian ZF, Wang PJ, Du SS. Chemical compositions and insecticidal activities of Alpinia kwangsiensis essential oil against Lasioderma serricorne. Molecules, 2015; 20:21939-21945.

\section{How to cite this article:}

Daud D, Alias NLR, Ali MTM, Tawang A. Physical Signs of Illness, Liver Functions and Reproductive Parameters of Female Rats Supplemented with Melaleuca cajuputi Methanolic Extract. J App Pharm Sci, 2018; 8(04): 139-142. 